\title{
Characteristics of Tropospheric Column Ozone over Taiwan
}

\author{
Chung-Ming Liu ${ }^{1, *}$ and Hsiu-Wu Chang ${ }^{2}$ \\ (Manuscript received 4 July 2000, in final form 20 February 2001)
}

\begin{abstract}
Analysis of total ozone data measured at Taipei and Chengkung in Taiwan, suggests that the spatial variation of column ozone over Taiwan is negligible. Further analysis of the ozone sonding data over Taipei indicates that the seasonal variation of total ozone is strongly correlated to the change of stratospheric ozone and has a typical pattern of spring maximum and winter minimum. The tropospheric ozone occupies about $16 \%$ of the total column ozone, and has maximum levels in spring and summer. Intrusions of stratospheric ozone and meridional ozone transport by the Hadley circulation have resulted in higher ozone levels in the upper and mid-troposphere in spring. Photochemical ozone production in the boundary layer is crucial to the summer maximum. Column ozone below $2 \mathrm{~km}$ height occupies about $3 \%$ of the total column and $18.6 \%$ of the troposphere ozone, which can be enhanced to $36 \%$ in July. Comparing this study's data with estimates from satellite data by Fishman et al. (1990), we note that there were changes of $-3.3 \%,-8.2 \%$ and $34 \%$ in the total, stratospheric and tropospheric ozone, respectively, from 1979 1987 to $1994 \sim 1999$. The tropospheric ozone-increasing trend is most noteworthy.
\end{abstract}

(Key words: Total ozone, Tropospheric ozone, Vertical ozone profile)

\section{INTRODUCTION}

Three factors are important to the distribution of tropospheric ozone (London and Liu 1992): downward transport of stratospheric ozone through tropopause folding (Roelofs and Lelieveld 1997), surface deposition and the photochemical production and loss. Levy et al. (1997) use a Global Chemical Transport Model to reveal that two largest components in the

\footnotetext{
${ }^{1}$ Department of Atmospheric Sciences, National Taiwan University, Taipei, Taiwan

${ }^{2}$ Central Weather Bureau, Taipei, Taiwan

${ }^{*}$ Corresponding author address: Prof. Chung-Ming Liu, Dept. of Atmospheric Sciences, National Taiwan University, \#1, section 4, Roosevelt Road, Taipei, Taiwan

E-mail: liucm@ccms.ntu.edu.tw
} 
global ozone budget are the stratospheric ozone injection and the surface dry deposition. Net contribution from tropospheric chemistry is relatively small (about one-fifth of the stratospheric injection), but is a balance between two large terms: production in the polluted boundary layer (about the same magnitude as the stratospheric injection) and destruction in the background troposphere. In the boundary layer, long-term anthropogenic emissions of ozone precursors from the industrialized Northern Hemisphere have enhanced surface ozone levels in Europe (Volz and Kley 1988; Marenco et al. 1994) and U.S. (Logon 1989, 1994). Meanwhile, biomass burning in the tropics results in significant ozone production in the lower troposphere and hence a strong seasonal correlation with the total ozone (Fishman et al. 1986; Badly et al. 1996; Kim and Newchurch 1997; etc.).

In past decades, strong economic growth in East Asia has drawn attention to studies concerning the human effect on regional tropospheric ozone. Ogawa and Miyata (1985), Tsuruta et al. (1989) and Sunwoo et al. (1994) reveal that surface ozone in Japan has a seasonal variation pattern of spring maximum and summer minimum. Akimoto et al. (1994) show that ozone in $0 \sim 2 \mathrm{~km}$ layer over Japan has been steadily increased in recent decades. Lee et al. (1998) point out an increase of about $2.5 \pm 0.6 \%$ per year of the ozone level in the lower tropospheric layer at Okinawa, Japan, and attribute this phenomenon to a steady increase of $\mathrm{NO}_{x}$ emissions from the Northeast Asian region. Chan et al. (1998) analyze ozone sonding data at Hong Kong and reveal tropospheric ozone maximum in spring and minimum in summer. They have attributed the later phenomenon to summer monsoon, which carries tropical clean air mass to this region.

In Taiwan, monitoring of total ozone can be traced back to the 1960s, but it was not until 1992, when two Brewer Spectrometers were set up at two separate sites, that the inter-compared datasets started to provide reliable information about local column ozone (Liu et al. 1995). These sites are at Taipei $\left(25^{\circ} \mathrm{N}, 121.3^{\circ} \mathrm{E}, 20 \mathrm{~m}\right)$ and Chengkung $\left(23.1^{\circ} \mathrm{N}, 121.4^{\circ} \mathrm{E}, 22 \mathrm{~m}\right)$, approximately $200 \mathrm{~km}$ apart along the same meridional line. The Brewer Ozone Spectrophotometer is a modified Ebert grating spectrometer, which uses axial slits to isolate five wavebands of interest. The intensity of each waveband is measured sequentially by a photomultiplier tube detector, and is recorded on separate channels in a microcomputer. The wavebands selected are centered at $306.3,310,313.5,316.8$ and $320 \mathrm{~nm}$ with a resolution of $0.6 \mathrm{~nm}$. The accuracy of ozone measurements is estimated to be $\pm 1 \%$ (Kerr et al. 1985).

In addition, a Vaisala ozonesonde station within $5 \mathrm{~km}$ from the total ozone site measures the vertical distribution of atmospheric ozone. A rawinsonde sensor and an ozonesonde sensor are attached to a plastic balloon and carried aloft. Under normal conditions, the whole detection process lasts for 2-3 hours and the balloon can reach an altitude of $30 \mathrm{~km}$. The Electrochemical Mixing ratio Cell (ECC) ozonesonde, developed by Komhyr (1969), has an accuracy range of $3-12 \%$ in the stratosphere when properly calibrated (Barnes et al. 1985). In operation, two sondes are released per month, but with frequently failed missions. In all, there were 24, 25, 21, 19, 15 and 15 sondings in 1994, 1995, 1996, 1997, 1998 and 1999, respectively. Sparse temporal coverage of ozone sondings prevents us from doing any trend analysis; but still a composite analysis of daily variation is useful to enhance our understanding about the ozone behavior over East Asian region. 


\section{COLUMN OZONE}

In general, total ozone over Taiwan has a range between $200 \sim 330$ D.U., with peak levels appearing in April $\sim$ May and minimum levels in December $\sim$ January. The root mean square value of the difference between the two stations' data is $12 \mathrm{D}$.U., which is only about $4.5 \%$ of the long-term mean 267 D.U. On average, total column ozone over Taipei is about 5.2 D.U. higher than that over Chengkung, with a correlation coefficient of 0.85 . Since Taipei and Chengkung are nearly along the same meridional line, but about $200 \mathrm{~km}$ apart, the analysis suggests that total ozone over Taiwan region has a negligible spatial variation.

Further analysis of the fractional deviation of the monthly average from the long-term monthly mean shows a clarified QBO (quasi-biennial oscillation) pattern, with spring maximums (5 8\%) in 1992, 1994, 1996 and 1998 and winter minimums (-4 -7 \%) in 1993, 1995, 1997 and 1999. No attempt is made here to estimate the long-term trend by the method outlined in WMO (2000), since only eight years of data are available here.

As to the ozone sonding data at Taipei, a total of 119 sondings are available for 1994 1999. The average maximum sonding height is about $35 \pm 7 \mathrm{~km}$. These data show a mean tropopause height of $17.4 \mathrm{~km}$. Maximum tropopause altitude of $19 \mathrm{~km}$ appears in March, while minimum of $16 \mathrm{~km}$ occurs in July, which is that typically observed by regular meteorological sondings. Minimum ozone number density about $2 \sim 4 \times 10^{11} \mathrm{\#} \mathrm{cm}^{-3}$ is at tropopause where the temperature is often lower than $-70^{\circ} \mathrm{C}$, while maximum ozone number density about $3.5 \sim 5.2 \times 10^{12} \mathrm{\#} \mathrm{cm}^{-3}$ appears at about $25 \mathrm{~km}$ height. Higher level of ozone number density in April May at $25 \mathrm{~km}$ height is associated with the observed maximum total ozone during the same period of time.

In Figs. 1a,b,c, temporal variation of total ozone (which was measured by Brewer spectrometer on dates when sondings were done), tropospheric column ozone and stratospheric column ozone are plotted. The stratospheric column ozone, which is obtained by subtracting the tropospheric column ozone from the total ozone amount, has a range between $180 \sim 275 \mathrm{D}$. U. with a mean level of 225 D.U., and has a seasonal variation pattern similar to that of total ozone. A high correlation coefficient of 0.85 exists between the stratospheric ozone and the total ozone. Meanwhile, tropospheric ozone varies between $24 \sim 78$ D.U. with a mean level of 43 D.U., and has high levels in April May and July August. The correlation coefficient between the tropospheric ozone and the total ozone-is about 0.53 . In all, tropospheric ozone contributes about $16 \%$ of the total column, with the fraction ranging between $7.5 \sim 27 \%$ (Fig. 1d). Higher fractions appear when the tropospheric ozone amount is at higher levels.

By comparing Figs. 1c,d with Figs. 4 and 5 in Chan et al. (1998), it is noted that the spring tropospheric ozone maximum appears also at Hong Kong with a maximum fractional contribution to the total ozone close to $27 \%$. Chan et al. (1998) suggest that photochemical production in the lower troposphere has made a significant contribution to spring maximums, while downward mixing of stospheric ozone also makes some contribution. But in summer, low tropospheric ozone near 20 D.U. appears at Hong Kong and is assumed to be associated with the cleari air mass coming from tropical maritime areas at levels below $2 \mathrm{~km}$ height. At Taipei, lowest tropospheric ozone near 24 D.U. occurs in November $\sim$ December. In summer tropospheric ozone has a range between $27.9 \sim 61.1$ D.U. There is no doubt that summer monsoon 
(a)

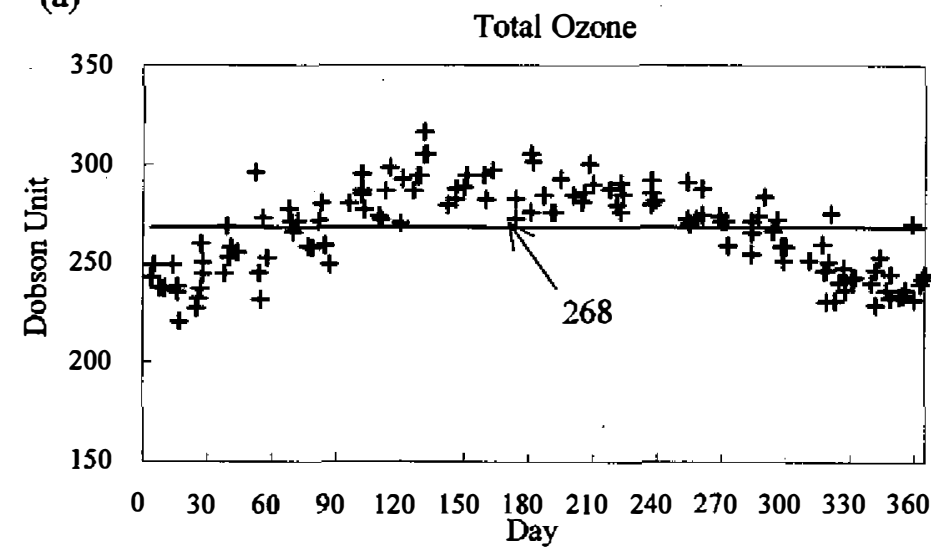

(c)

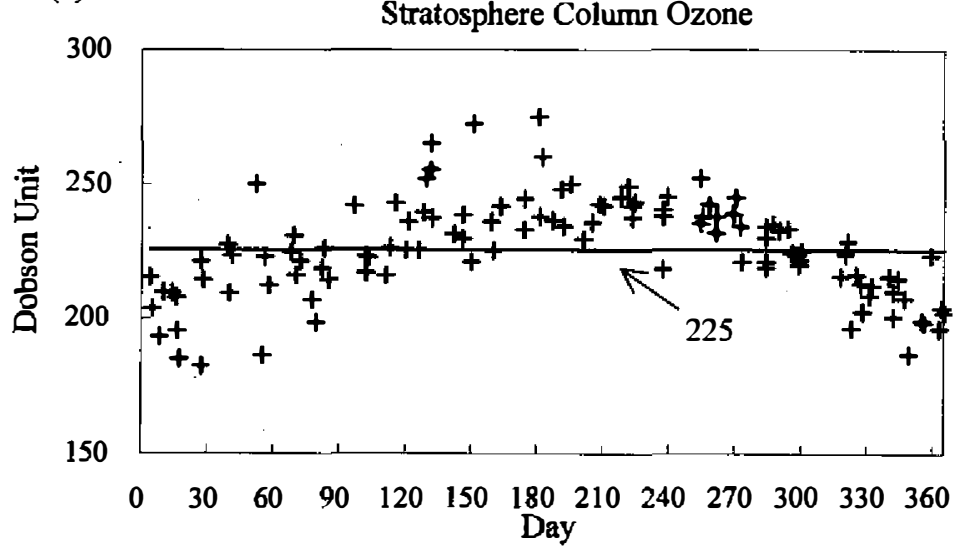

(b)

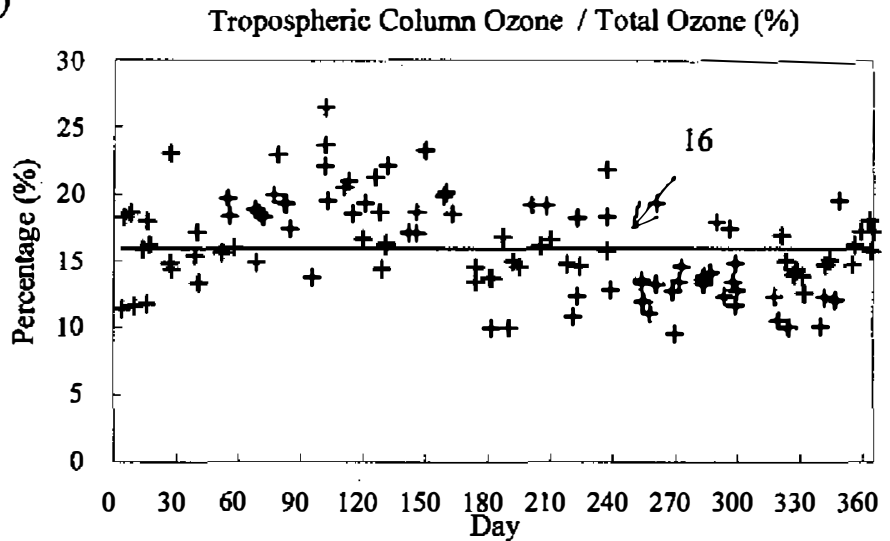

(d)

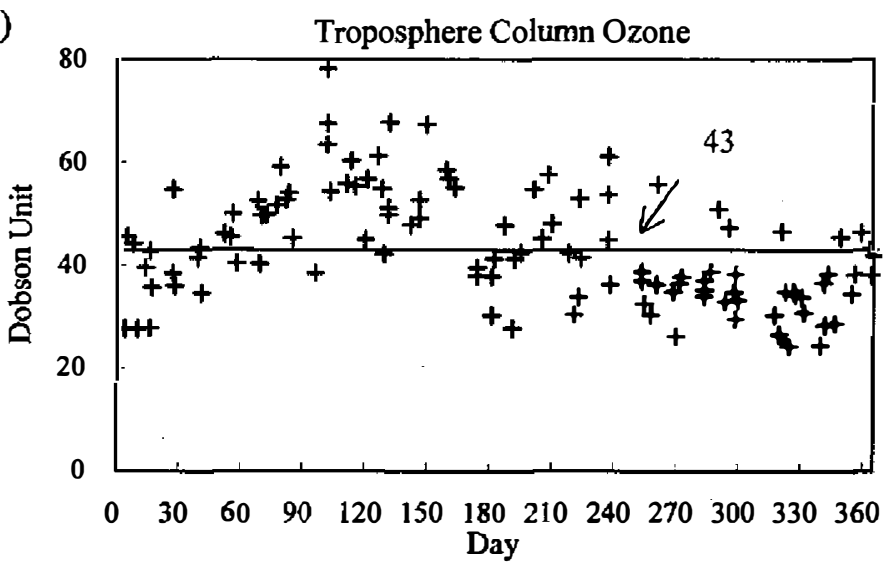

Fig. 1. (a) Total ozone measured by Brewer spectrometer at Taipei on the same day when ozone sondings were done; (b) the column ozone amount below tropopause; (c) the stratospheric column ozone, which is obtained by subtracting the tropospheric column ozone from the total column amount; and (d) the fraction of ropospheric column ozone in the total ozone amount. 
also carries clean maritime air mass to the Taipei region (Liu et al. 1995), but anthropogenic emission of ozone precursors probably contributes more to enhance the photochemical production of ozone locally.

Fishman et al. (1990) analyze the 22,000 TOMS observations coincident with the SAGE profiles between 1979 and 1987 to derive the global distribution of total ozone, stratospheric ozone and tropospheric residual. Over the Taiwan region, the column amount retrieved is about 277, 245 and 32 D.U. for the total, stratospheric and tropospheric column, respectively. In this study, our analyses indicate that the mean total, stratospheric and tropospheric ozone is about 268, 225 and 43 D.U., respectively, during $1994 \sim 1999$. Decrease of the stratospheric ozone from 1979 1987 to $1994 \sim 1999$ is accompanied with a gentle increase in the troposphere, and hence a weak decrease in the total column ozone. The change is about $-3.3 \%,-8.2 \%$ and $34 \%$ for the total, stratospheric and tropospheric ozone, respectively. Clearly, the tropospheric ozone-increasing trend is much higher than the stratospheric ozone-decreasing trend, while the magnitude of the total ozone-decreasing trend is close to that estimated in WMO (2000). There is no doubt that the characteristics of the data retrieved by Fishman et al. (1990) from TOMS and SAGE are not the same as those of ozonesonde data, but still such comparison of data provides a useful and preliminary estimation of a long-term changing trend over this area.

\section{VERTICAL VARIATION OF TROPOSPHERIC OZONE}

To analyze the vertical variation of tropospheric ozone, composite plots of ozone number density and mixing ratio below $20 \mathrm{~km}$ height are shown in Fig. 2. In the troposphere, ozone molecules are abundant at the surface and increase after January to $12 \mathrm{~km}$ height in April, then decrease afterward (Fig. 2a). In the meantime, higher ozone mixing ratio exists in the stratosphere and decreases downward to the surface (Fig. 2b). In April, a tongue of higher ozone mixing ratio extends downward from the tropopause to the surface. Similar phenomena have been observed at Hong Kong (Chan et al. 1998) and many other sites in the Northern Hemisphere. It is a large-scale seasonal phenomenon, associated with the intrusion of stratospheric air, large-scale transport by Hadley circulation and the photochemical production from anthropogenic emission of precursors (Danielsen 1968; Fishman and Crutzen 1978; Liu et al. 1987). Over Eastem Asia, photochemical production at lower levels seems to contribute strongly to the April maximum of tropospheric ozone mixing ratio (Chan et al. 1998). After April, the ozone mixing ratio below $6 \mathrm{~km}$ is decreased, just as that observed at Hong Kong, but is not down to 5ppbv in June $\sim$ July as shown in Chan et al. (1998). This is possible because the sonding site is in the Taipei basin, which is a polluted area with elevated ozone levels. Low surface mixing ratio occurs in autumn when the northeasterly monsoon starts to prevail.

The ozonesonding data in the troposphere can be divided into upper troposphere $(8 \mathrm{~km} \sim$ tropopause), mid-troposphere ( $2 \sim 8 \mathrm{~km})$ and planetary boundary layer (PBL, $0 \sim 2 \mathrm{~km})$. Each layer occupies about 40,42 and $18 \%$, respectively, of the tropospheric ozone, and has a mean level about 17, 18, and 8 D.U., respectively. Figure 3 shows that higher amounts occur in spring in the upper and mid-troposphere, and in April and July in the PBL. Lower amounts occur in winter in all three layers. Clearly, photochemical production is an important ozone source in the PBL, while intrusion of stratospheric ozone and meridional ozone transport by 
(a)

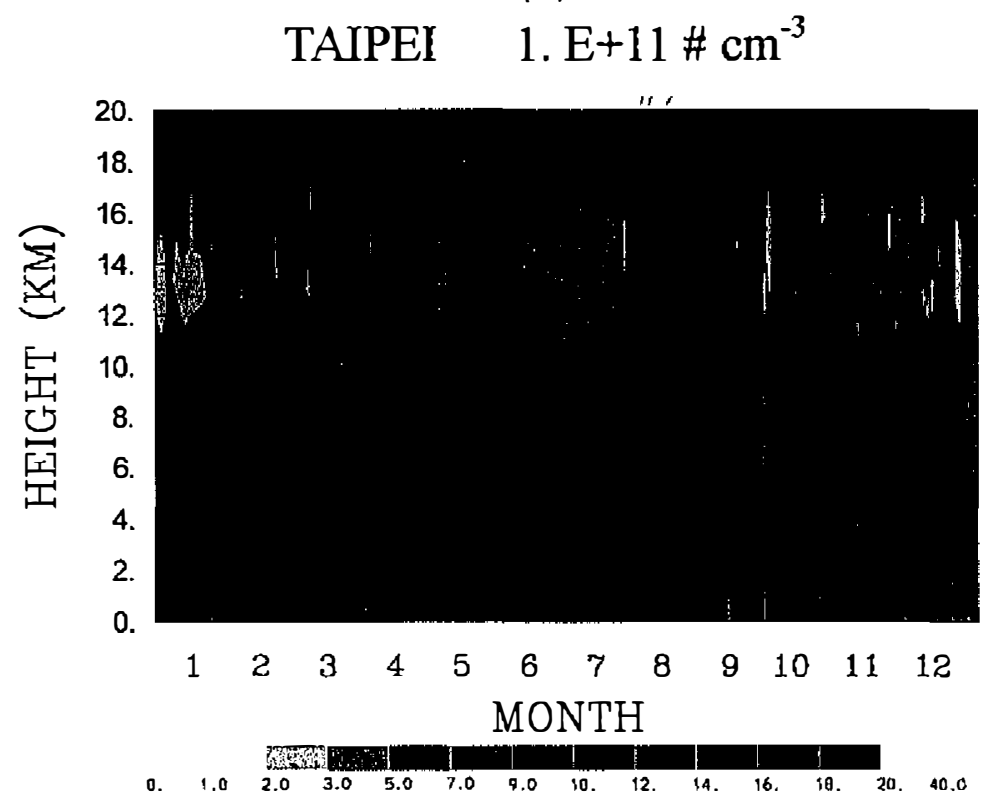

(b)

TAIPEI PPBV

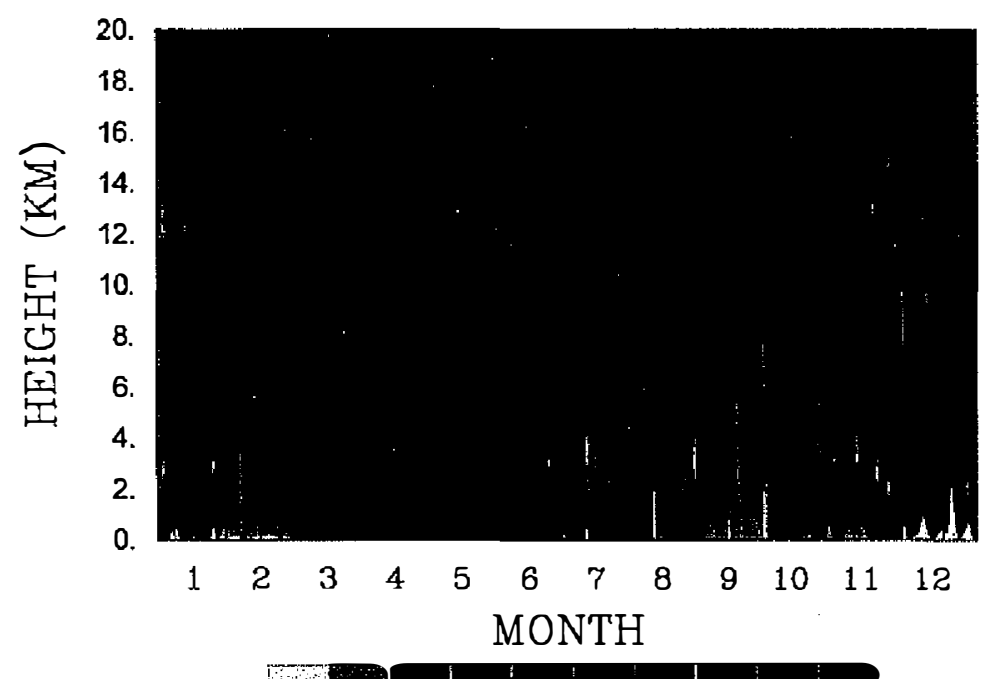

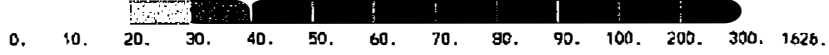

Fig. 2. Height-time composite plots of (a) ozone number density ( $\mathrm{x} 10^{\mathrm{il}} \#_{\mathrm{cm}^{-3}}$ ) and (b) ozone mixing ratio (ppbv) below $20 \mathrm{~km}$ height. 

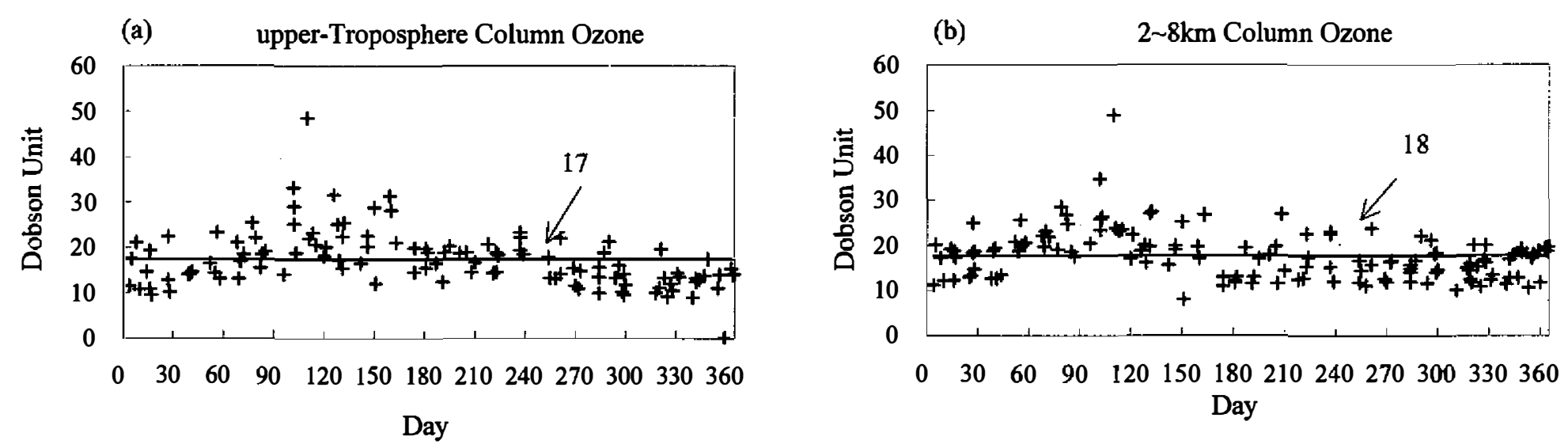

(c)

\section{2km (PBL) Column Ozone}

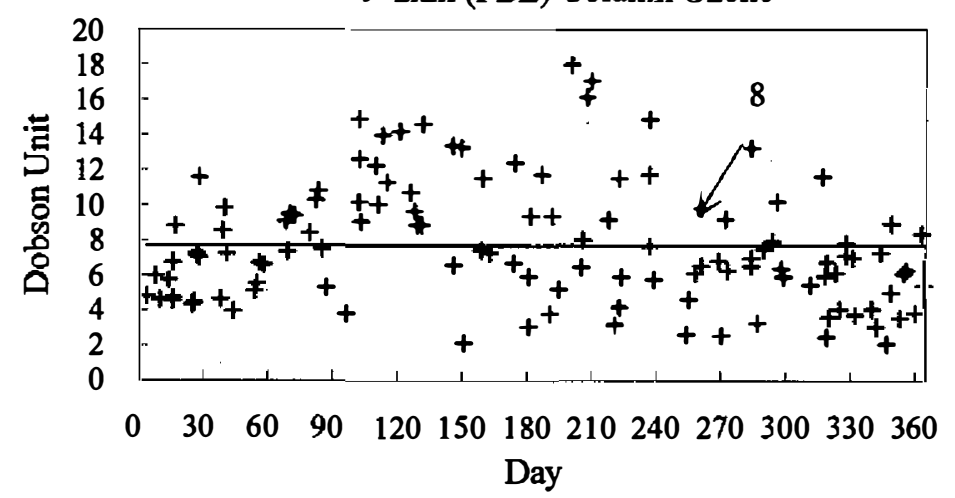

(d) PBL / Troposphere Column Ozone (\%)

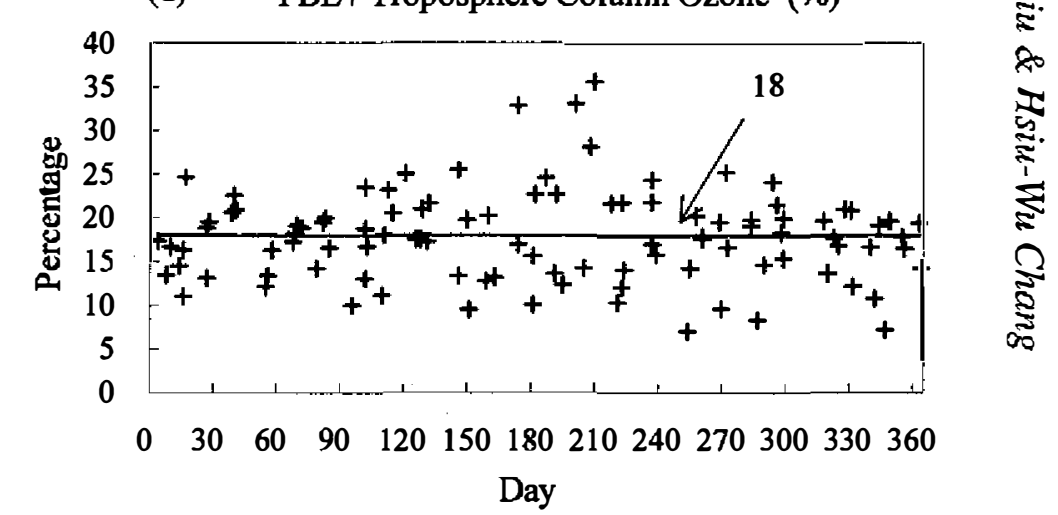

Fig. 3. Daily variation of column ozone amount in (a) upper roposphere (between $8 \mathrm{~km}$ and tropopause), (b) midroposphere (between $2 \sim 8 \mathrm{~km}$ level) and (c) PBL (planetary boundary layer, below $2 \mathrm{~km}$ height), and the fraction of PBL ozone in the tropospheric column. 
the Hadley circulation strongly affects the variation of ozone amount in the upper and midroposphere (Chan et al. 1998). The contribution of PBL ozone is about 7.5 36\% (Fig. 3d) and is most important in summer.

Selected ozone number density and mixing ratio profiles on 94/4/12, 95/7/20, 96/10/10 and 97/1/8 are illustrated in Figs. 4a,b to provide a clearer picture of vertical variation in the troposphere. The highest ozone amounts from surface to tropopause appear in April, while low amounts appear in January and October. Near the surface, low photochemical production of ozone has caused low ozone amounts in January and October. In July, ozone amounts in the planetary boundary layer (PBL) are comparable to April levels, which are associated with effective photochemical production in summer over the polluted Taipei basin. In all, the most dramatic change of ozone level occurs in the PBL with a low level at surface and a sharp increase of ozone amount upward toward a peak level just below the PBL height. On 95/7/20, the surface ozone-mixing ratio was about $80 \mathrm{ppbv}$, while the peak level of about $135 \mathrm{ppbv}$ occurred at $1.6 \mathrm{~km}$ height.

To understand more clearly the importance of photochemical production of ozone at the surface, we have analyzed the data monitored by the local EPA (Environmental Protection Administration) at Wanli (located on northern coast), Panchiao (in the Taipei basin, near the ozonesonding site) and Yanmingsam (a mountain site, $827 \mathrm{~m}$ altitude, located in northem Taipei). Wanli is considered the northern background station, and Panchiao is in the polluted Taipei basin, while Yanmingsam is in the national park. Figure 5a shows the monthly-mean dailymaximum ozone level during $1993 \sim 1999$, while Fig. 5b illustrates the monthly-mean daytime range (the difference between noontime maximum and 6am ozone level). It is no surprise that the largest monthly-mean daily-maximum and daytime range appears in summer at Panchiao, while at Wanli and Yanmingsam, the largest daily-maximum occurs in April and May, with maximum daytime range in summer. Since the magnitude of ozone daytime range indicates the efficiency of photochemical activities, the maximum value in summer at all three stations supports the importance of photochemical production in the PBL, which is just like that indicated in the ozone sonding profiles. Interestingly, the maximum monthly-mean daily-maximum at Wanli and Yanmingsam appears in spring, which does support the importance of upstream ozone transport associated with the intrusion of stratospheric ozone in the mid-latitudes and the southward transport by continental airmass. Still, the contribution from photochemical production cannot be ignored in spring, as indicated from the large monthly-mean daytime ozone range shown in Fig. $5 \mathrm{~b}$.

\section{SUMMARY AND CONCLUSION}

Total ozone measured at Taipei is highly correlated with that measured at Chengkung. Even though the former is slightly higher than the latter, the difference is below $5 \%$ of the long-term mean. Hence, it is reasonable to consider that the spatial variation of total ozone over Taiwan is negligible.

Seasonal variation of total ozone is characterized by spring maximum and winter minimum, which is strongly correlated with the variation in the stratosphere. Tropospheric ozone contributes about $16 \%$ to total column ozone, and has maximum levels in spring and summer. 
(a)

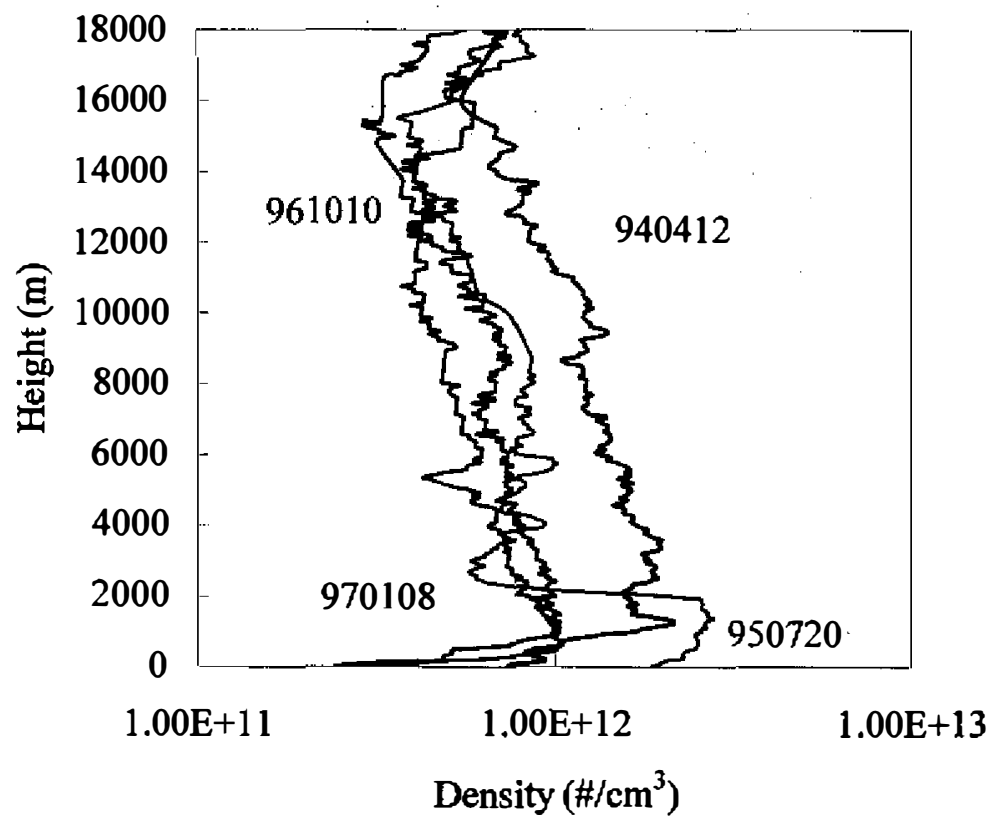

(b)

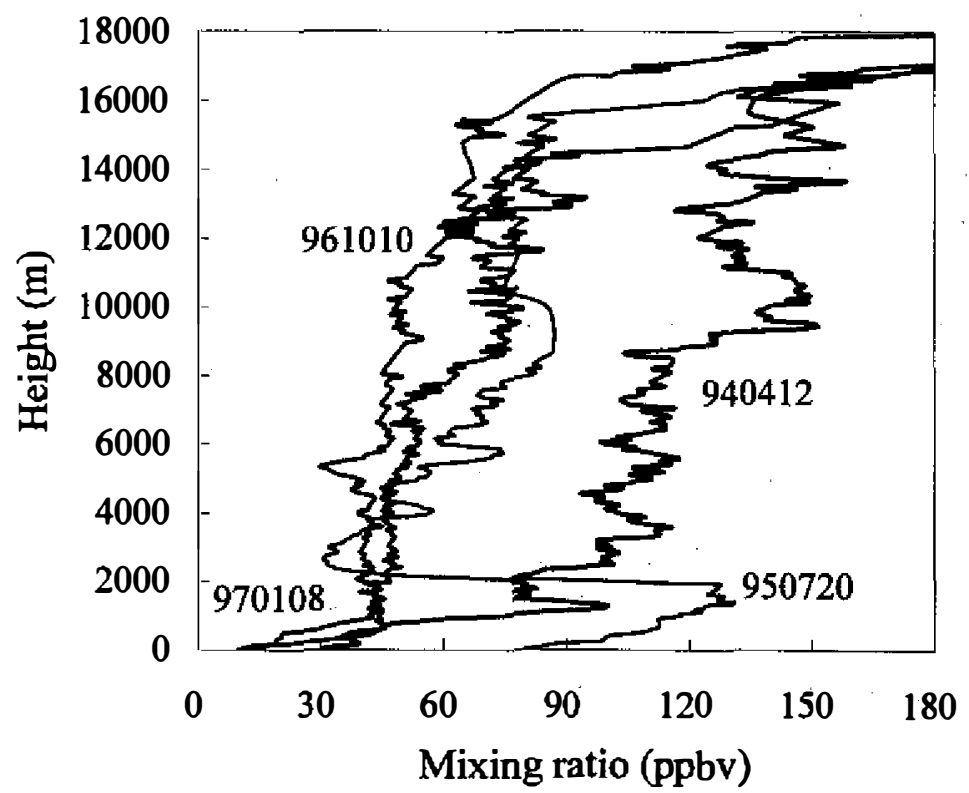

Fig. 4. Selected ozone profiles on $94 / 4 / 12$, 95/7/20, 96/10/10 and 97/1/8 in the unit of (a) number density $\left(\# \mathrm{~cm}^{-3}\right)$ and (b) mixing ratio (ppbv). 
(a) monthly-mean daily-max.
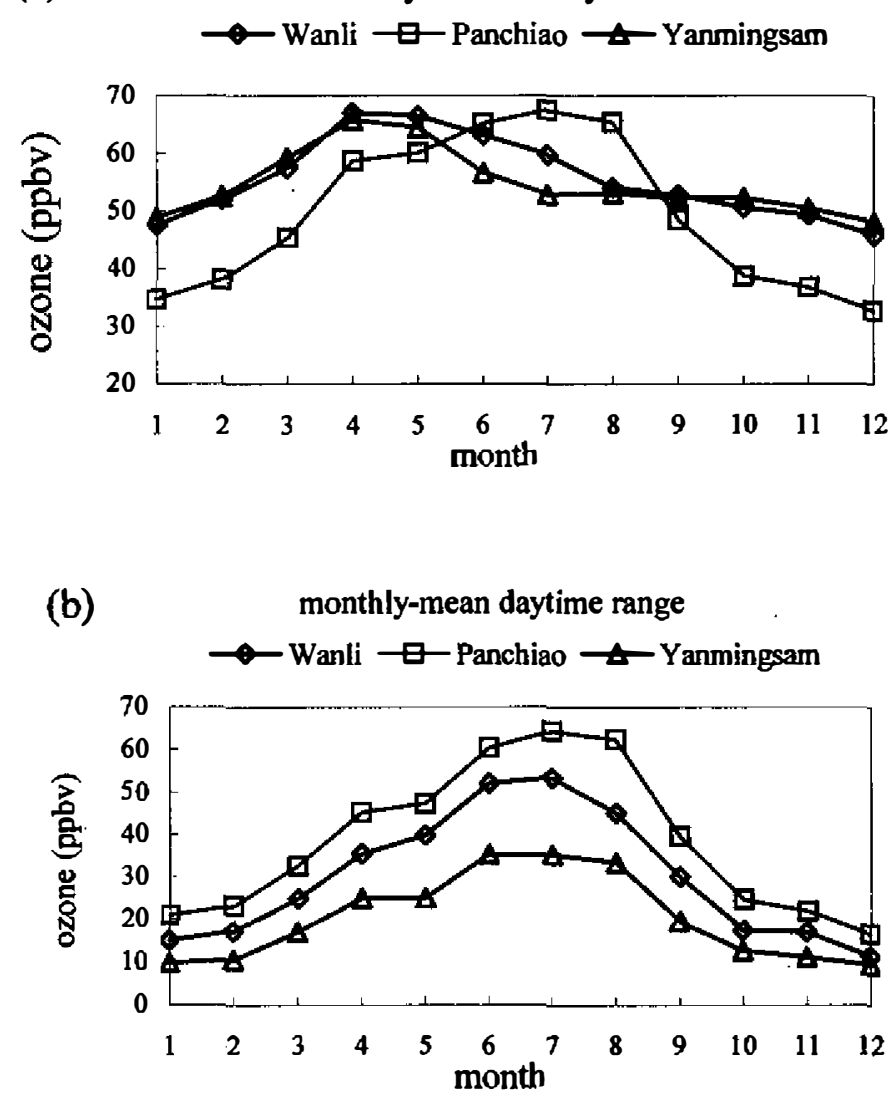

Fig. 5. The monthly-mean (a) daily-maximum and (b) daytime range of ozone level at Wanli, Panchiao and Yanminsam.

Intrusions of stratospheric ozone and meridional ozone transport by the Hadley circulation have resulted in the spring maximum in the upper and mid-troposphere. While photochemical production in the boundary layer can never be ignored in the Taipei basin, and has caused higher ozone levels in summer than those observed by Chan et al. (1998) at Hong Kong. The PBL column ozone is about $2 \sim 18$ D.U. and has a mean level of 8 D.U, which is only $3 \%$ of the total ozone. Its contribution to the mopheric ozone is about $7.5 \sim 36 \%$ and has a mean level of $18 \%$. Higher contributions occur in summer. Study of the vertical ozone profile indicates a sharp increase of ozone mixing ratio from surface to a peak level just below the PBL height. There is no doubt that photochemical production in spring and summer affects the PBL ozone level strongly.

Comparing this study's data with that outlined in Fishman et al. (1990), we note that a decrease of stratospheric ozone from 245 D.U. during $1979 \sim 1987$ to 225 D.U. during 1994 1999 was accompanied with a gentle increase in the troposphere (from 32 D.U. to 43 D.U.), and hence a weak decrease in the total column ozone (from 277 D.U. to 268 D.U.). The change 
was about $-3.3 \%,-8.2 \%$ and $34 \%$ for the total, stratospheric and tropospheric ozone, respectively. The tropospheric ozone-increasing trend was much higher than the stratospheric ozone-decreasing trend, while the magnitude of the total ozone-decreasing trend was close to that estimated in WMO (2000).

Acknowledgements This paper was prepared under the support of National Science Council grant NSC-88-2111-M-002-011 and NSC-89-2111-M002-009. The author wants to thank Central Weather Bureau for providing all necessary data and Prof. Shaw C. Liu for valuable suggestions.

\section{REFERENCES}

Akimoto, H., H. Nakane, and Y. Matsumoto, 1994: The chemistry of oxidant generation: Tropospheric ozone increase in Japan. In: J. Calvert (Ed.), Chemistry of the Atmosphere: The Impact on Global Change, 261-273, Blackwell Science Publication, Oxford.

Baldy, S., G. Ancellet, M. Bessafi, A. Badr, and D. Lan Sun Luk, 1996: Field observations of the vertical distribution of tropospheric ozone at the island of Reunion (southern tropics). J. Geophys. Res., 101, 23835-23849.

Barnes, R. A., A. R. Bandy, and A. L. Torres, 1985: Electrochemical mixing ratio cell ozonesonde accuracy and precision. J. Geophys. Res., 90, 7881-7887.

Chan, L. Y., H. Y. Liu, K. S. Lam, and T. Wang, 1998: Analysis of the seasonal behavior of tropospheric ozone at Hong Kong. Atmos. Environ., 32, 159-168.

Danielsen, E. F., 1968: Stratospheric-tropospheric exchange based on radioactivity, ozone and potential vorticity. J. Atmos. Sci., 25, 502-518.

Fishman, J., and P. J. Crutzen, 1978: The origin of ozone in the troposphere. Nature, 274, 855-858.

Fishman, J., P. Minnis, and H. G. Reichle Jr., 1986: Use of satellite data to study tropospheric ozone in the tropics. J. Geophys. Res., 91, 14451-14465.

Fishman, J., C. E. Watson, J. C. Larsen, and J. A. Logan, 1990: Distribution of tropospheric ozone determined from satellite data. J. Geophys. Res., 95, 3599-3617.

Kerr, J. B., C. T. McElroy, D. L. Wardle, R. A. Olaison, and W. E. J. Evans, 1985: Atmospheric ozone. Proceeding of Quadrennial Ozone Symposium, 1984. In: C. S. Zerefos and A. Ghazi (Eds.), 396, D. Reidl.

Kim, J. H., and M. J. Newchurch, 1996: Climatology and trends of tropospheric ozone over the eastern Pacific Ocean: The influence of biomass burning and tropospheric dynamics. Geophys. Res. Letters, 23, 3723-2726.

Komhyr, W. D., 1969: Electrochemical mixing ratio cells for gas. Annals of Geophysics, 25, 203-210.

Lee, S., H. Akimoto, H. Nakane, S. Kumosenko, and Y. Kinjo, 1998: Lower tropospheric ozone trend observed in 1989-1997 at Okinawa, Japan. Geophys. Res. Letters, 25, 16371640.

Levy II, H., P. S. Kasibhatla, W. J. Moxim, A. A. Klonecki, A. I. Hirsch, S. J. Oltmans, and W. L. Chameides, 1997: The global impact of human activity on tropospheric ozone. 
Geophys. Res. Letters, 24, 791-794.

Liu, S. C., M. Trainer, F. C. Fehsenfeld, D. D. Parrish, E. J. Williams, D. W. Fahey, G. Hubler, and P. C. Murphy, 1987: Ozone production in the rural troposphere and the implications for regional and global ozone distribution. J. Geophys. Res., 92, 41914207.

Liu, C.M., C.-J. Lin, H.-W. Change, and S.-M. Chou, $1995^{\circ}$ GOzone monitoring in Taiwan. In Atmospheric Ozone as a Climate Gas. In: W.-C. Wang and I.S.A. Isaksen (Eds.), NATO ASI Series, vol. 32, p.289-304. Springer, Berlin.

Logan, J. A., 1989: Ozone in the rural areas of the United States. J. Geophys. Res., 94, 85118532.

Logan, J. A., 1994: Trends in vertical distribution of ozone: an analysis of ozonesonde data. $J$. Geophys. Res., 99, 25555-25585.

London, J., and S. C. Liu, 1992: Long-term tropospheric and lower stratospheric ozone variations from ozonesonde observations. J. Atmos. and Terrestrial Physics, 54, 599-625.

Marenco, H., P. Gouget, J. Nedelec, P. Pages, and F. Karcher, 1994: Evidence of a long-term increase in tropospheric ozone from Pic du Midi data series: consequences: positive radiative forcing. J. Geophys. Res., 9, 16617-16632.

Ogawa, T., and A. Miyata, 1985: Seasonal variation of the tropospheric ozone: a summer minimum in Japan. J. Meteorology Soc. Japan, 63, 937-946.

Roelofs, G.-J., and J. Lelieveld, 1997: Model study of the influence of cross-tropopause $\mathrm{O}_{3}$ wansports on tropospheric $\mathrm{O}_{3}$ levels. Tellus, 49B, 38-55.

Sunwoo, Y., G. R. Carmichael, and H. Ueda, 1994: Characteristics of background surface ozone in Japan. Atmospheric Environment, 28, 25-37.

Tsuruta, H., K. Shinya, T. Mizouguchi, and T. Ogawa, 1989: Seasonal behavior of the tropospheric ozone in rural Japan. In Ozone in the Atmosphere. In: R. D. Bojkov and P. Fabian (Eds.), 433-436, Deepak, Hampton, Va.

World Meteorological Organization, 2000: Scientific Assessment of Ozone Depletion, 2000. WMO Publication.

Voltz, A., and D. Kley, 1988: Evaluation of the Montsouris series of ozone measurements made in the nineteenth century. Nature, 332, 240-242. 